\title{
French engineers and social thought, 18-20th centuries: An archeology of technocratic ideals.
}

\section{Citation}

Picon, Antoine. 2007. French engineers and social thought, 18th - 20th centuries: an archeology of technocratic ideals. History and Technology 23, no.3: 197-208.

\section{Published Version}

doi:10.1080/07341510701300262

\section{Permanent link}

http://nrs.harvard.edu/urn-3:HUL.InstRepos:10537042

\section{Terms of Use}

This article was downloaded from Harvard University's DASH repository, and is made available under the terms and conditions applicable to Other Posted Material, as set forth at http:// nrs.harvard.edu/urn-3:HUL.InstRepos:dash.current.terms-of-use\#LAA

\section{Share Your Story}

The Harvard community has made this article openly available.

Please share how this access benefits you. Submit a story.

Accessibility 
FRENCH ENGINEERS AND SOCIAL THOUGHT

$18^{\mathrm{TH}}-20^{\mathrm{TH}}$ CENTURIES,

\title{
AN ARCHEOLOGY OF TECHNOCRATIC IDEALS
}

\author{
Antoine PICON \\ Harvard University, Graduate School of Design, USA. E-mail: \\ apicon@gsd.harvard.edu
}

During the second half of the twentieth century, at the time of the foundation of the Fifth Republic, French engineers endorsed enthusiastically technocratic ideals. Their attitude was not only the product of a specific context. It was rooted in a long tradition of connection between French engineering and social preoccupations. This connection emerged at the time of the creation of the first corps of State engineers in the seventeenth and eighteenth centuries. Indeed, State engineers were from the start convinced that they had a social mission. Subsequent episodes, like the Saint-Simonian reflections on the eve of industrialization, or the discussions held in the think tank X-Crise in the aftermath of the 1929 economic crisis contributed also to shape the engineers' sensitivity to social issues. Dwelling on these episodes, but also trying to go beyond their standard assessment, we would like to propose here a more general interpretation of the complex set of relations between French engineering and social thought. In this perspective, the Post-World-War-II French engineers' technocratic concerns come at the end of a long and complex evolution. This case study should enable a better understanding of the more general connivance between engineering culture and technocratic ideals.

\section{INTRODUCTION}


Technocracy may be defined as the tendency to give precedence to technological competence over political legitimacy, to rational administration over the hazards of public debate. Whereas the word was coined in the United States during the first half of the twentieth century, the attitude it designates is more pervasive and elements of it can be traced back to previous periods. ${ }^{1}$ In the French case, the technocratic attitude adopted by many engineers after World War II, an attitude that reached its climax during the first years of the Fifth Republic (1958 - ), must be replaced in the more general frame of an enduring connection between engineering and social preoccupations, a connection probably stronger than in some other countries.

This connection is to a certain extent imputable to the role played by the state in the history of the French engineering profession. The point has been made by various authors, from philosophers and economists like Friedrich August von Hayek to historians like Kenneth Alder, Gabrielle Hecht or Bruno Belhoste. ${ }^{2}$ But the complex set of relations between French engineering and social thought are not entirely reducible to this aspect. Our ambition here is to provide a more detailed account of the emergence and transformation of French engineers' social views from the eighteenth century to the twentieth, and to contribute thus to a better understanding of why and how they became technocratic at a certain point.

This study reveals a mix of specific features and of characteristics shared by engineers all over the world. Once the distinction has been made between the specific and the more generic, a better understanding of the connection between engineering culture at large and technocratic ideals becomes possible using French engineers as a case study. As we will argue, these engineers were not technocratic from the start, not even at the time of the Revolution or during the first half of the nineteenth century. Their trajectory is nevertheless representative of general cultural features that have been present for a long time among

\footnotetext{
1 On the American origin of the term, see infra. Since elements constitutive of technocratic ideals can be traced back to former historical periods, it is possible to use the term for these periods. This is what Bruno Belhoste and Konstantinos Chatzis have chosen to do in their article "From Technical Corps to Technocratic Power" published in the present issue. We prefer as for us to reserve the term to twentieth-century movements.

2 Von Hayek, The Counter-Revolution of Science; Alder, Engineering the Revolution; Hecht, The Radiance of France; Belhoste, La Formation d'une Technocratie.
} 
engineers, features that may explain the emergence of technocratic ideals among them in the twentieth century.

\section{FRENCH ENGINEERING AND SOCIAL AWARENESS: A BRIEF HISTORICAL OUTLINE}

A series of key episodes have shaped French engineers sensitivity to political and social questions prior to the emergence of a distinctive technocratic attitude in the second half of the twentieth century. Rather than episode, the terms layer or stratum are probably more appropriate here; for each of these episodes has left its imprint and their superimposition is part of the distinctive identity of French engineering culture. What we would like to propose here is a kind of archeology of French engineers' sense of social responsibility, a sense of social responsibility that explains their subsequent adherence to technocratic ideals.

The first of these episodes is the military foundation of the engineering profession in the sixteenth and seventeenth centuries. In France, engineering emerged as an activity related to war, to fortification in particular. Until the Enlightenment, engineers were officers generally belonging to the nobility. These military roots entailed a certain number of key characteristics. Among them, one finds the engineers' firm belief to belong to an elite defined by virtues of courage and knowledge. This elitist streak was further reinforced by the organization of the fortification engineers in a corps towards the end of the seventeenth century, an organization that was soon to serve as a model for other branches of engineering. ${ }^{3}$ Beside elitism, corporatism was to remain another enduring feature of the French engineering profession. A last key element was the accent put on mathematics, an accent that derived from the importance given to them in aristocratic education. For the young aristocrat eager to serve in the army, arithmetic and geometry proved essential. Mathematics was not - this is worth noting - conceived as a pure exercise of the mind, rather as a tool for action, from artillery and fortification to infantry deployment calculations. This conception of mathematics not as an abstract set of theories but as the formalization of very practical

3 Blanchard, Les Ingénieurs du "Roy" de Louis XIV à Louis XV. 
questions was to remain characteristic of French engineering. ${ }^{4}$ It explains, among other things why French engineers engaged very early in economics problems and calculation. 5 To this day, a substantial number of French economists are still trained initially as engineers, contrary to the situation that prevails in many other countries where economics has less links with engineering.

Until the end of the seventeenth century, the engineer was not accountable to society as such. He was primarily obeying the orders of the king, orders that could differ vastly from what his subjects might wish. This situation imparted the engineers with the conviction that authority was the outcome of an institutional legitimacy different from allegedly direct forms of popular expressions. There again, this belief was to remain an enduring feature of French technological elites. In France, direct democracy was never seen as a natural way to take major technological decisions, the most recent example of this attitude being the nuclear policy on which French people were never consulted.

In the archeology of French engineering social awareness, the eighteenth century represents probably one of the most important episodes. It is the moment when the profession emancipated itself from its military roots with the creation of a whole range of civil corps, the Ponts et Chaussées corps in charge of the construction of roads, bridges and canals, or the Mines corps in charge of mining and industrial questions. 6 Under the influence of the new political ideals of the time, State engineers began to define themselves as contributors to public utility and progress. The progress they had in mind was not only material. It possessed a strong moral connotation since prosperity was seen as the key to regenerated social relations.

The transformation of engineering education in a school-based system, with the creation of institutions like the Ecole des Ponts et Chaussées (1747), the Ecole du

\footnotetext{
4 This crucial point is missing from Eda Kranakis otherwise excellent comparative study: Constructing a Bridge.

5 The work of Jules Dupuit is perhaps the best example of this early interest. Cf. Ekelund and Hebert, Secret Origins of Microeconomics. For a broader picture of the contribution of engineers to economics and economic calculation, see Etner, Histoire du Calcul Economique en France; F. Vatin, Le Travail.

6 See among others Blanco, Stato e Funzionari nella Francia del Settecento; Picon, L'Invention de l'Ingénieur Moderne; Thépot, Les Ingénieurs des Mines du XIXe Siècle.
} 
Génie (1748), the Ecole des Mines (1783), and the Ecole Polytechnique (1794), represents another key element in the picture. It reinforced the elitist nature of the profession by transforming it gradually into a meritocracy based on the mastery of advanced science, analytical geometry, calculus, mechanics, physics and chemistry among others. Although this transformation was accomplished only around the 1820s in the curriculum of the Ecole Polytechnique and its dependent "schools of application", its premises were already discernible in the educational agenda of an institution such as the Ecole du Génie who produced major eighteenth-century scientists like Charles-Augustin Coulomb or Pierre-Georges Dubuat. 7

The most important legacy of the Enlightenment remained however the connection established between material and moral progress as well as the conviction held by engineers that they were indeed serving public welfare. The moral connotation proved especially important for them; engineering, civil engineering in particular, was about determining what was good or bad for the people. Beside the traditional role model of the officer, another reference appeared in the texts of the time, in the writings of the Ponts et Chaussées engineers in particular, the one of the judge in charge of deciding what is in the best interest of those who come before his court. French eighteenth-century State engineers tended to see themselves as judges in charge of determining which the most useful projects were for the community. 8

This evolution led to a more ambitious vision of what technology could achieve for the benefit of all. Comprehensive territorial and urban planning emerged during that period. Ponts et Chaussées engineers envisaged for instance the transformation of the entire French kingdom into an artfully designed garden like territory. With this new kind of project, links began to appear between engineering and utopia. These links developed in a spectacular way during the first half of the nineteenth century.

${ }^{7}$ Cf. Taton, Enseignement et Diffusion des Sciences en France au XVIII e siècle; Gillispie, Science and Polity in France at the End of the Old Regime.

8 This conception represents a major difference between French engineers and their British counterparts. See on that subject Picon, "Technological Traditions and National Identities." 
Two phenomena marked actually the first half of the nineteenth century. The first one was the emergence of a series of debates regarding the relations that were to prevail between public policies and private initiatives. Who was to pay for instance for the transportation infrastructures constructed by the State, for the canals and railways in particular; whom should manage them, administration or private companies? These crucial questions fostered the development of modern political economy and economic calculation, two domains with which French engineers were immediately conversant, thus deepening their concern with the broader repercussions of their action.

As mentioned above, the strong connection between engineering and social utopia represents another key phenomenon. Around 1830, engineers were for example extremely present in a utopian movement like Saint-Simonianism. ${ }^{9}$ According to von Hayek, the roots of modern engineering technocratic ideals were to be found in the Saint-Simonian doctrine and its advocacy of a totally organized society in which scientific and technological competence must take precedence on traditional social distinction. 10

Despite its seduction, this kind of analysis must be however nuanced. For technological competence was supposed to yield to spiritual power in the perfect society envisaged by the Saint-Simonians. In many ways, the importance they gave to this competence was a follow-up to the Enlightenment conception of the almost judicial nature of engineering. In the Saint-Simonian religious frame, the judge of public interest became an apostle of progress, but the general perspective remained similar.

The most fundamental tendency at work through the adherence of so many engineers to Saint-Simonianism, and later to Fourierism, had rather to do with a profound denial of the fecundity of political and social conflict. The SaintSimonian doctrine was all the more attractive to engineers that it presented itself as an antidote to violent conflict between haves and have-nots. The denial of the role played by conflict in social dynamics will remain an enduring feature of the French engineering profession, contrary to countries like Greece, Algeria or

\footnotetext{
9 Cf. Picon, Les Saint-Simoniens.

10 Hayek, The Counter-Revolution of Science.
} 
Vietnam, for instance, where engineers will be at the forefront of revolutionary fight. ${ }^{11}$ This explains among other things the very weak appeal of Marxism on a profession who will always favor class cooperation over class struggle.

The second half of the nineteenth century was probably less decisive in the genesis of the French engineers' technocratic ideals. It was nevertheless marked by a fundamental evolution: the diversification of a profession that gradually extended beyond its administrative cradle. ${ }^{12}$ Towards the end of the century, civil and mechanical engineers working for the private sector had become far more numerous than State engineers. Their social conceptions remained however strikingly close to those of their colleagues, rooted in the firm belief in the utility of the engineer, in his capacity to transcend the interests of his immediate employer to serve the common good. The preservation of this common frame of thought was made possible by the very peculiar nature of the relation between the public and the private sector that had emerged at the time: a relation apprehended in terms of interpenetration, hybridization rather than clear-cut opposition. Coined later, the expression "économie mixte" conveys well the nature of this intimacy between public and private interests that still characterizes France today.

One has actually to wait until the beginning of the twentieth century to observe the first unequivocal expressions of technocratic ideals among French engineers. Their emergence is almost contemporary with similar developments in the United States. The French term "technocratie" is actually an importation from the American word technocracy invented to name a program of political and economical reform that would empower the engineers and more generally the scientific and technological experts. ${ }^{13}$ Jut like their American counterparts, in the early 1930s, the think tank $X$-Crise, created by former graduates of the Ecole Polytechnique in order to identify solutions to the post-1929 economic slump advocated the replacement of existing political structures by a scientific and

\footnotetext{
11 The comparison between the political itineraries of French alumni of the Ecole Polytechnique and of some of their Foreign colleagues is especially revealing in that respect. See Karvar, "Les Polytechnciens Etrangers et les Mouvements Nationaux." On the Greek case, one should mention the definitive work of Y. Antoniou: Oi Ellines Michanikoi (The Greek Engineers). See also Antoniou et al., "The National Identity of Inter-war Greek Engineers," in the present issue.

12 See for instance Weiss, The Making of Technological Man; Auclair, Les Ingénieurs et l'Equipement de la France; Garçon, Entre l'Etat et l'Usine.

13 Cf. Layton, The Revolt of Engineers; Akin, Technocracy and the American Dream.
} 
technology-based power. ${ }^{14}$ The young and ambitious civil servants that gathered later around the Vichy government in the aftermath of the 1940 collapse of almost all the political structures of the Third Republic (1871-1940) were also guided by the conviction that traditional politics had to be replaced by rational management based on science and technology. ${ }^{15}$

Various factors converged to explain this evolution. Some were by no means specific to the French scene, like the growing dissatisfaction of engineers in front of the recurring and seemingly sterile confrontations between Capital and Labor that occurred in most industrialized countries. Frederick Winslow Taylor's scientific management was from the start intended as a possible solution to this problem, a solution precisely based on the mediation of technological competence in order to make compatible the exigencies of employers and workers. It is no coincidence if most early-twentieth-century technocracy-leaning engineers were fervent supporters of scientific management.

The 1929 crisis and the massive unemployment problems that followed represent another common factor to countries like France and the United States. ${ }^{16}$ The frustrations it created fueled the desire for an alternative political organization giving precedence to a rational management of people and resources, a rational management seen as the only solution to unemployment.

The various episodes evoked previously and their legacy, like the French engineers' conviction to belong to an elite or their conception of their social role, played also a fundamental role. Recurring practices, like the elaboration of ambitious plans for territories, cities and infrastructures, gave also their technocratic ideals a specific tone. France's technological trajectory was marked by a series of vast programs or "plans", from the 1821-1822 "Plan Becquey" aiming at the completion of French canals to the 1967 "Plan Calcul" meant to foster French computing industry. ${ }^{17}$ The connection between technocratic

\footnotetext{
14 X-Crise, De la récurrence des crises économiques.

15 Brun, Technocrates et Technocratie en France (1914-1945).

16 On the French situation created by the 1929 crisis, see Grelon, Les Ingénieurs de la Crise.

17 On this tendency to conceive grand programs, see Smith, "The Longest Run: Public Engineers and Planning in France." On the "Plan Calcul", see Pierre Mounier-Kuhn, "Le Plan Calcul, Bull et l'Industrie des Composants."
} 
attitudes and planning was to represent an important feature of Post-War French modernization through institutions like the DATAR, the Délégation à l'Aménagement et à l'Action Régionale, created in 1963 to coordinate the territorial enterprises of the State. ${ }^{18}$

The first decade of the Fifth Republic coincided with the culmination of the technocratic ideals of the French engineering profession. For the first time, these ideals translated further into a set of concrete practices that changed the visage of France. While the Mines engineers corps launched an ambitious nuclear program, the Ponts et Chaussées administration was busy planning giant infrastructures and new towns with an authority it had never possessed to such a degree before.

Despite their authoritarian character, these practices were never as radical in their attempt to dismiss traditional political mechanisms as those led by proponents of operation research and system analysis in some bureaucratic circles of the United States, from the rationalization of the Department of Defense decisions to the urban renewal enterprises led in the name of Lyndon Johnson's "Great Society". 19 There again, clichés must be avoided. For centuries of association between the French engineering profession and the elites ruling the country provided the former with a political culture that many American technocrats of the 1950s and 1960s did not possess. Even in the most technocratic phase of their history, French engineers did not envisage an almost complete substitution of rational decisions methods to traditional political deliberation. For sure, in matters like nuclear policy or territorial and urban planning, political deliberation was not as dependent on popular vote in France as similar questions were in the United States. But this lesser degree of dependence diminished the temptation to get totally rid of politics. Somewhat paradoxically, the less democratic nature of French technological policies was also what limited their transformation into totally technocratic procedures.

After its early 1960s climax, French technocratic ideals and practices began to recede. Society was changing at a rapid pace, and the events of 1968 marked the emergence of new generations that were not longer ready to accept passively

\footnotetext{
18 Cf. Laborie et al., La PolitiqueFrançaise d'Aménagement du Territoire.

19 See for instance Hughes and Hughes, Systems, Experts, and Computers; Light, From Warfare to Welfare.
} 
technological policies developed in the name of public welfare by State engineers. In the later decades, this dismissal of technocratic ideals and practices was to take various forms, from the systematic opposition to the nuclear industry fueled by ecological movements groups to the severe criticism of modern urbanism and landscape led by all sorts of groups, from politics to occupants associations.

\section{REFLECTIONS ON THE FRENCH SPECIFICITY}

Taking stock, the history of the French engineering profession bears the mark of a series of paradoxes. First, contrary to the common assumption, the true technocratic episodes come relatively late in an evolution which is marked by a collusion between technological and traditional political elites rather than by their opposition one to another. A second paradox stems from the fact that French engineers are from the start decidedly non-specialized and somewhat messianic in their approach of technology as well as in their ambition to use it to service society. This generalist and messianic perspective, so fundamentally different from their British counterparts more pragmatic point of view, is also among the features that make them so specific.

This specificity is rooted in the seminal role played by the State in the emergence of the profession. One must note however that France is not the only country where the State has been so influential on engineering. Spain, Russia or even the United States with the Army Corps of Engineers represent other cases. A series of features must be taken into account to understand better the French situation.

Among the most important ones, one finds the existence of the "économie mixte", this hybrid of public initiative and private capital that has marked for so long French economic life. ${ }^{20}$ Without such a twilight zone it would have been more difficult for engineers to maintain their claim to be working for public welfare even when they were privately employed. It is only recently, under the pressure of globalization, that this feature has been receding.

\footnotetext{
20 See for instance on that key French legal and economical notion: S. Guérard, Regards Croisés sur l'Economie Mixte.
} 
Another key feature of the French scene is the moral and cultural legitimacy of the State, there again an aspect that has begun to decline only a few years ago. Until then, the State was seen as the only true guarantor for civic values and social bond. Through State-controlled intellectual, scientific and artistic institutions like academies and schools, the public sector was also invested with an indisputable cultural legitimacy. Since its most prestigious schools were public, engineering education was among the beneficiaries of such a situation.

The consequence of this moral and cultural legitimacy was the trust that was granted to the State and its engineers, a trust without equivalent in the United States, as Theodore Porter has shown in an enlightening comparative essay. 21 Without this public trust, policies like the civil nuclear program would have sooner or later met a strong opposition from some politicians as well as from the people. Public trust was also among the factors that limited somewhat the technocratic temptation among post-War French engineers. Why indeed oppose scientific and technological competence to political legitimacy, when the latter readily recognized the value of the former?

Another specificity of French engineering is its judicial inspiration. More than mere technicians, French engineers, especially the members of preeminent State corps, have a tendency to consider themselves as arbitrators of interests. Many engineers have tried to achieve this status all over the world. In France, at least for the higher levels of the profession, it was something almost evident.

The importance given to a general, relatively abstract and mathematics-based education is related to that last feature. Until the present day, it is not a know-how that one is supposed to learn in a prestigious French engineering school, but principles comparable to the fundamentals of law. In this type of institution, the link between mathematics and economics is interpreted in the same perspective. Economics is seen as an essential instrument in order to arbitrate between often divergent interests.

These ideological structures account partly for the precedence given to cooperation rather than conflict that characterizes French engineer's social

21 Porter, Trust in Numbers. 
approach. French engineers have always had a tendency to reason in terms of negotiation and adjustments rather in terms of blunt confrontation. For a sociologist initially trained as engineer (at Ecole des Mines de Paris) like Michel Callon, the embrace of the science studies credo can be interpreted in such a perspective. $^{22}$ But putting the accent on process of mutual adaptation within networks of actors instead of emphasizing their brutal fight for power, the science studies theoretical frame is strangely in tune with the traditional social vision of French engineering elites.

Finally, the history of French engineering leaning presents a striking case where political discontinuities are counterbalanced by strong continuities within the profession itself. Despite the impact of events ranging from the 1789 revolution to the 1940 collapse of the Third Republic, the study of French engineering social conceptions and technocratic inclinations reveals a progressive evolution rather than a series of dramatic breaks.

This story is different in that respect from what has happened in other countries where the engineering profession was profoundly changed by political events to which engineers participated actively. Whereas engineers were extremely present in the political history of countries like Greece, Algeria or Vietnam, as we have mentioned it before, French engineers kept a relatively lower political profile. ${ }^{23}$ In France, with the exception of the Terror and its so-called "revolutionary productions", there was no profound connection between revolution and the concern for technological progress carried by the engineering profession. 24 Technology and engineering were indeed associated to progressive ideals. But they were supposed to put an end to revolution, to make it impossible in the SaintSimonian perspective, rather than foster it. Despite almost two centuries of evolution, French engineers never totally repudiated this perspective.

22 The engineers of the Mines corps have a long tradition of social concern. They were especially present in the Saint-Simonian movement and later in movements like $X$-Crise. This social concern has also permeated the other alumni of the Ecole des Mines, the civil engineers like Michel Callon. 23 The Third Republic represents in that respect an exception. See Marnot, Les Ingénieurs au Parlement sous la IIIe République.

24 On the episode of the "revolutionary productions", see Dhombres and Dhombres, Naissance d'un Nouveau Pouvoir. 


\section{LESSONS FROM A CASE STUDY}

Now, what can we learn from the French case? Despite its strong peculiarities, it presents features that are perhaps more general than one might think at first. What it tends to suggest is that engineering history bears a closer link to social ideals and strategies than to industrial techniques and technologies proper.

Contrary to a common assumption, the role played by engineers in industrial change is often difficult to assess precisely. For a very long time, industry had little use of engineers. This was especially the case in France where they were concentrated in domains like civil engineering and construction. 25 They proved however crucial as soon as technology and industry became synonymous with complex problems of organization, of social organization to be more precise. In other words, despite affirmations to the contrary, often emanating from representatives of the profession, engineers may very well of relatively minor importance in many processes of innovation. After all, most of them hold positions of production management in which organizational skills are more important than mere technological inventiveness.

In a profession that tends to assimilate technology to technological and social organization, the technocratic temptation is no accident. It appears rather as the result of an unavoidable evolution, an evolution constitutive of the engineer's identity in our societies. There again, the French trajectory is rather extreme since engineering is from the start understood as a social activity, but it is simultaneously paradigmatic.

The depth of the link between engineering and concerns of social organization and welfare explains why we are confronted with a profound crisis of the engineer's identity these days. With the demise of former beliefs regarding the equivalence between technological progress and social welfare, the very ideological bases of the engineering profession are undermined. Nowhere is this situation more evident than among French State engineers whose usefulness is more and more openly challenged.

25 Machine builders were not considered as engineers. Cf. Edmonson, "From Mécanicien to Ingénieur." 
Once again, taking the full measure of French engineering history specificity is a precondition for truly convincing comparative studies. It would be interesting to put side by side in that perspective the French technocratic circles of the 1930s, like $X$-Crise, and their American counterparts. In the same vein some French Fifth Republic engineering practices are close to contemporary American cybernetic and systemic endeavors. The present situation of incertitude is also calling for comparative studies between well-identified local and national situations.

If one looks at the evolution of engineering history as a discipline, one cannot but be struck by the successive shifts in its fundamental assumptions. At the beginning, this history was centered on the allegedly universally valid achievements of engineering, while interpreting them at the same time and not without inconsequence as embodiments of national geniuses. In a later phase, engineering history became more precise and local, while paying attention to the circulation of patterns and models from one local scene to another. This was the time when one spoke readily of a French or a British model influencing countries like the United States, Russia or Egypt. ${ }^{26}$ Today, historians have become probably even more aware of local specificities to a point that makes it difficult to speak of models and to reduce international exchanges to their circulation. It does not mean that nothing circulate, far from it. As I have tried to show in this paper, French engineering is both much more specific than one supposed - so specific that characterizations based on factors like the importance played by the State remain probably too general to constitute a sufficient explanation - and representative of broader issues present in many other national situations. The problem then becomes how to explain phenomena of coincidence or convergence like the technocratic leaning common to so many engineers throughout the world towards the mid twentieth century. Because of this kind of problem, and despite the identity crisis currently encountered by engineers, we still have a lot to learn from engineering history.

26 See for instance Ghilaine Alleaume, L'Ecole Polytechnique du Caire et ses Elèves; Grelon et al., La Formation des Ingénieurs en Perspective. 


\section{REFERENCES}

Akin, William E. Technocracy and the American Dream: The Technocrat Movement 1900-1941. Berkeley and Los Angeles: University of California Press, 1977.

Alder, Ken. Engineering the Revolution: Arms and Enlightenment in France, 1763-1815. Princeton: Princeton University Press, 1997.

Alleaume, Ghilaine. "L'Ecole Polytechnique du Caire et ses Elèves: La Formation d'une Elite Technique dans l'Egypte du XIXe Siècle." Ph.D. Diss., Université Lyon II, 1993.

Antoniou, Yiannis. Oi Ellines Michanikoi, 1900-1940. Thesmoi kai Idees (The Greek Engineers 1900-1940. Ideas and Institutions). Athens: Vibliorama, 2006.

Auclair, Alain. Les Ingénieurs et l'Equipement de la France. Eugène Flachat (1802-1873). Le Creusot: Ecomusée de la Communauté urbaine Le CreusotMontceau-les-Mines, 1999.

Belhoste, Bruno. La Formation d'une Technocratie: L'Ecole Polytechnique et ses Elèves de la Révolution au Second Empire. Paris: Belin, 2003.

Blanchard, Anne. Les Ingénieurs du "Roy" de Louis XIV à Louis XVI: Etude du Corps des Fortifications. Montpellier: Université Paul Valéry, 1979.

Blanco, Luigi. Stato e Funzionari nella Francia del Settecento: Gli "Ingénieurs des Ponts et Chaussées". Bologna: Il Mulino, 1991.

Brun, Gérard. Technocrates et Technocratie en France (1914-1945). Paris: Albatros, 1985.

Dhombres J., and N. Dhombres. Naissance d'un Nouveau Pouvoir: Sciences et Savants en France (1798-1824). Paris: Payot, 1989.

Ekelund, Robert B., and Robert Hébert. Secret Origins of Modern Microeconomics: Dupuit and the Engineers, Chicago: University of Chicago Press, 1999.

Etner, François. Histoire du Calcul Economique en France. Paris: Economica, 1987.

Garçon, Anne-Françoise. Entre l'Etat et l'Usine. L'Ecole des Mines de SaintEtienne au XIXe Siècle. Rennes: Presses Universitaires de Rennes, 2004.

Gillispie, Charles Coulston. Science and Polity in France at the End of the Old Regime. Princeton: Princeton University Press, 1980.

Grelon, André, ed. Les Ingénieurs de la Crise. Titre et Profession Entre les Deux Guerres. Paris: Editions de l'EHESS, 1986. 
Grelon A., A. Karvar, and I. Gouzevitch, eds. La Formation des Ingénieurs en Perspective: Modèles de Référence et Réseaux de Médiation XVIIIème-XXème Siècle. Rennes: Presses Universitaires de Rennes, 2004.

Guérard, Stéphane, ed. Regards Croisés sur l'Economie Mixte. Paris: L'Harmattan, 2006.

Hayek, Friedrich August von. The Counter-Revolution of Science. 1952, new ed. New-York: Free press of Glencoe, London, Collier-Mac-Millan, 1955.

Hecht, Gabrielle. The Radiance of France: Nuclear Power and National Identity after World War II. Cambridge, Masschusetts; MIT Press, 1998.

Hughes A. C., and T. P. Hughes, eds. Systems, Experts, and Computers: The System Approach in Management and Engineering, World War II and After. Cambridge, Masschusetts: MIT Press, 2000.

Karvar, Anousheh. "Les Polytechiens Etrangers et les Mouvements Nationaux." In La France des X: Deux Siècles d'Histoire, edited by B. Belhoste, A. DahanDalmedico, D. Pestre and A. Picon. Paris: Economica, 1995.

Kranakis, Eda. Constructing a Bridge: An Exploration of Engineering Culture, Design, and Research in Nineteenth-Century France and America. Cambridge, Massachusetts: MIT Press, 1997.

Laborie, J.-P., J.-F. Langumier, and P. de Roo. La PolitiqueFrançaise d'Aménagement du Territoire de 1950 à 1985. Paris: La Documentation française, 1985.

Layton, Edwin T. The Revolt of Engineers: Social Responsibility and the American Engineering Profession. 1971, new ed. Baltimore: John Hopkins University Press, 1986.

Light, Jennifer S. From Warfare to Welfare: Defense Intellectual and Urban Problems in Cold War America. Baltimore, London: Johns Hopkins University Press, 2003.

Marnot, Bruno. Les Ingénieurs au Parlement sous la IIIe République. Paris: CNRS Editions, 2000.

Edmonson James M., "From Mécanicien to Ingénieur: Technical Education and the Machine Building Industry in Nineteenth-Century France." Ph.D. Diss., University of Delaware, 1981.

Mounier-Kuhn, Pierre. "Le Plan Calcul, Bull et l'Industrie des Composants: Les Contradictions d'une Stratégie." In Actes $d u$ 3e colloque Histoire de l'informatique, Sophia-Antipolis: INRIA, 1993. 
Picon, Antoine. L'Invention de l'Ingénieur Moderne: L'Ecole des Ponts et Chaussées, 1747-1851. Paris: Presses de l'Ecole nationale des Ponts et Chaussées, 1992.

-------. "Technological Traditions and National Identities: A Comparison between France and Great Britain during the 19th Century." In Science, Technology and the 19th Century State, edited by E. Nicolaïdis and K. Chatzis, Athens: Neohellenic Research Institute, 2000.

Picon, Antoine. Les Saint-Simoniens: Raison, Imaginaire et Utopie. Paris: Belin, 2002.

Porter, Theodore M. Trust in Numbers: The Pursuit of Objectivity in Science and Public Life. Princeton: Princeton University Press, 1995.

Smith, Cecil O. "The Longest Run: Public Engineers and Planning in France." The American Historical Review 95 (1990): 657-692.

Taton, René, ed. Enseignement et Diffusion des Sciences en France au XVIII siècle. Paris: Hermann, 1964.

Thépot, André. Les Ingénieurs des Mines du XIXe Siècle: Histoire d'un Corps Technique d'Etat (1810-1914). Paris: ESKA, 1998.

Vatin, François. Le Travail: Economie et physique 1780-1830. Paris: P.U.F., 1993.

Weiss, John H. The Making of Technological Man: The Social Origins of French Engineering Education. Cambridge, Massachusetts: MIT Press, 1982.

$X$-Crise: De la récurrence des crises économiques. Son cinquantenaire (19311981). Paris: Economica, 1982. 